\title{
MEDICINAL GREEN WAVE AND ITS REGULATION IN BRAZIL
}

\section{ONDA VERDE MEDICINAL E SUA REGULAÇÃO NO BRASIL}

\section{MARIANA RIBEIRO SANTIAGO}

Pós-Doutora em Direito pela Justus-Liebig-Universität Giessen (Alemanha). Doutora e Mestre em Direito pela Pontifícia Universidade Católica de São Paulo - PUCSP. Professora do Programa de Pós-Graduação em Direito da Universidade de Marília UNIMAR. Editora-Chefe da Revista Argumentum. Membro do Projeto Harmony with Nature, de iniciativa das Nações Unidas. Advogada. E-mail: mariana@nbsadvogados.com.br.

\section{ALCEU TEIXEIRA ROCHA}

Doutorando e Mestre em Direito pela Universidade de Marília - UNIMAR. Mestre em Direito do Consumidor pela Universidade de Santos. Professor Universitário UNIFAI de Adamantina. Advogado. E-mail: atradvogado@hotmail.com.

\section{ANA PAULA BARBUY CRUZ}

Especialista em Direito Penal Econômico pela Fundação Getúlio Vargas. Associada ao Instituto de Defesa do Direito de Defesa. Fundadora do Projeto Di Alma. Advogada. E-mail: ana.paula@nbsadvogados.com.br.

\section{ABSTRACT}

Objective: The study aims the use of cannabis for medicinal purposes in Brazil, which has already been legalized, with an emphasis on the import and planting of seeds in the national territory, still without regulation, and the axiological gap resulting from such legal framework. The study also points out the medicinal properties of cannabis that have already been scientifically proven and to clarify how to resolve the aforementioned controversy over its regulation in the national territory. 
Methodology: The method of approach followed is the legal dialectical, covering the phenomenon, fact and theory, simultaneously, seeking the result with complement between the both. To obtain the results desired by the work, bibliographic research was used, covering specialized works.

Results: The release of the import and planting of cannabis seeds in Brazil, for medicinal purposes, is a result of the right to health, the application of the principles of human dignity, equality and social solidarity, as well as the principles of economic activity.

Contributions: The choice of the theme is justified considering that, in addition to the proven efficiency of cannabis in the treatment of serious diseases, socially there is still great prejudice on the theme, which is reflected in the legal area.

Keywords: Cannabis; right to health; human dignity; principles; axiological gap.

\section{RESUMO}

Objetivo: O presente artigo aborda o uso da cannabis para fins medicinais no Brasil, já legalizado, com ênfase para a importação e o plantio da semente em território nacional, ainda pendente de regulamentação, e a lacuna axiológica decorrente de tal quadro; O estudo também aponta as propriedades medicinais da cannabis já comprovadas cientificamente e esclarecer como sanar a mencionada controvérsia sobre a sua regulamentação no território nacional.

Metodologia: O método de abordagem seguido é o dialético jurídico, cobrindo o fenômeno, fato e teoria, simultaneamente, buscando o resultado com complemento entre os dois. Para a obtenção dos resultados desejados pelo trabalho, foi utilizada pesquisa bibliográfica, abrangendo trabalhos especializados.

Resultados: A liberação da importação e do plantio da semente de cannabis no Brasil, para fins medicinais, é uma decorrência do direito à saúde, da aplicação dos princípios da dignidade humana, da igualdade e da solidariedade social, bem como dos princípios da atividade econômica.

Contribuições: A escolha do tema justifica-se tendo em vista que, a par da comprovada eficiência da cannabis no tratamento de doenças graves, socialmente ainda se verifica grande preconceito sobre o tema, o que se reflete na área jurídica.

Palavras-chave: Cannabis; direito à saúde; dignidade humana; princípios; lacuna axiológica. 


\section{INTRODUCTION}

The advancement of technologies is evident today, including in the field of medicine. It collaborates through scientific knowledge to demystify prejudices regarding green medicine. Brazil, due to the recent positioning of the National Health Surveillance Agency - ANVISA, is in the middle of the discussions spread around the world about the risks of the legalization of marijuana and other natural drugs, mainly for medicinal purposes.

In this sense, questions arise whether the green medicinal wave can bring risks to the health of the population, expanding the recreational use of marijuana. On the other hand, whether the legalization is an imperative precisely because it allows the appropriate treatment of certain diseases in which traditional medicine has not been successful.

Resolution of the Collegiate Board no. 327, of December 9, 2019, issued by the National Health Surveillance Agency - ANVISA, allowed the use of cannabis for medicinal purposes in Brazil. However, it was omitted in relation to the import and planting of the seed in national territory, even if under supervision, creating a technical conflict of high relevance to the Brazilian law.

The choice of this is justified by the need to clarify the issues related to the use of cannabis for medicinal purposes. In addition to its proven efficiency in the treatment of serious diseases; socially, there is still great prejudice on the subject, which is reflected in the contradictions and omissions observed in the rules related to it.

This research aims to point out the medicinal properties of cannabis that have already been scientifically proven. In addition, the purpose is to clarify how to resolve the aforementioned controversy over its regulation in the national territory. This exercise is in line with the right to health and the fundamental bases of the Federal Constitution.

Initially, it is outlined the evolution of the regulation of cannabis for medicinal purposes in Brazil. Afterwards, when the normative technical deficiency is found, 
which jeopardizes the consistency of the legal system, solutions are proposed through the general principles of law.

The method of approach followed is the deductive, covering the phenomenon, fact and theory, simultaneously, seeking the result with complement between the both. To obtain the results desired by the work, bibliographic research was used, covering specialized works.

\section{THE EVOLUTION OF CANNABIS REGULATIONS FOR MEDICAL PURPOSES IN BRAZIL}

Cannabis is one of the oldest known plants, with information on its use dating back more than 4000 years ago in the Chinese Pharmacopoeia.

Cannabis is of paramount importance in the treatment of various diseases. However, Brazilian legislation historically prohibits its use, including for medicinal purposes. This prohibition is derived from the historical speeches related to the plant, which will be addressed in the sequence of this work.

The first documented use of cannabis was approximately 2300 b.C. in China. On that occasion, Chen Nong prescribed the use of the plant for the treatment of constipation, blood complications, rheumatism and fever. In the 19th century, the English empress Conquista, similarly used marijuana for the treatment of menstrual cramps (ROBINSON R, 1999, p. 13).

Specific evidence shows that cannabis arrived in Brazil in the era of regency, also with the application of its fibers. However, the first slaves who used it as a narcotic discovered the plant a long time ago. It shows that the hallucinogen also had therapeutic characteristics (MOREAU, 2008, p. 13).

Cannabis is a complex plant with several cannabinoids present in its composition, each one with a different effect and also with the possibility that some of them change the effect of others. As an example, cannabidiol (CBD), which is a substance present in cannabis, according to studies is considered free of 
psychotropic effects, reduces anxiety, causes a general feeling of well being and contributes to concentration. In addition to being effective as a medicine, cannabidiol reduces the effects of tetrahydrocannabinol (THC) (BURGIERMAN, 2011, p. 44).

For cannabis to be considered medicinal in Brazil, it must contain a maximum of $0.3 \%$ tetrahydrocannabinol, this level being 33 times lower than that found in less potent marijuana. Thus, in the case of cannabidiol it is impossible for a user to feel any psychoactive effect with the simple use of the substance (SOUBHIA, 1999, p. 7).

Moreover, marijuana, although also derived from cannabis, is cultivated exclusively for its psychoactive properties that cause hallucinogenic effects, as it has very high tetrahydrocannabinol levels. It is important to note that marijuana varieties can have tetrahydrocannabinol concentrations between $5 \%$ and $10 \%$ (SOUBHIA, 1999, p. 7).

According to Pedrinha (2008, p. 5.488), upon the involvement of the bourgeoisie, drugs started to become regulated and/or prohibited. Base on this prohibition that Brazil moved to the repressive aspect of criminology, mainly in the middle of the 20th century, a period in which people began to be arrested due to its use, especially in relation to substances considered illegal by the State, even marijuana.

The peak of drug use in Brazil occurred during the colonial period. The Portuguese constitution was the first to indicate prohibited substances. In the Philippines Ordinances of 1603, in Cousa Livro, article LXXXIX, the use, possession and sale of some substances considered toxic, such as realgar, soporiferous etc., had penalties with seizure of assets and exile (PEDRINHA, 2008, p. 5.489).

Brazil assumed the prohibitionist and criminalizing systems influenced by the organizations of the United States, in which the use of substances was associated with debauchery, crime and alienation. In addition, the arrest was foreseen for merchants, considering buyers as sick, suffering from drugs (VIDAL, 2009, p. 64).

Open consumption in Brazil comes from the beginning of the 20th century, when it became a "relevant social difficulty" (before that use had been observed for centuries, but was a object of prejudice and related to marginalized people with few 
plantations dedicated to the manufacture of fibers and fabrics). Moral combat was adopted, although it was disguised as a rigorous scientific analysis (FRANÇA, 2015, p. 56).

Advances in scientific research demonstrate that cannabis can be used to treat many diseases, such as glaucoma, anorexia and cachexia associated with AIDS; chronic pain, inflammation, such as rheumatoid arthritis; Crohn's disease, nausea, lack of appetite and different harmful effects caused by chemotherapy; or treatment of AIDS and cancer, reduced appetite, advanced Alzheimer's, insomnia, hepatitis C, Parkinson's, Tourette's syndrome, multiple sclerosis (reduces spasms, muscle tightness, lack of sleep and pain); depression, asthma and epilepsy, decreasing epileptic seizures in patients who have diseases resistant to some other type of medication, such as Dravet's syndrome (BEZERRA, 2019, p. 10).

Another great advantage of marijuana is the possibility of its use as a harm reduction agent in the treatment of crack users, according to research by Rowan Robinson:

For 12 months, psychiatrists followed a group of 20 addicts who were smoking marijuana in an attempt to lessen the compulsion and anxiety caused by crack. At the end of the study, 14 of them - 70\% of the group had abandoned crack use and were smoking marijuana sporadically (MASSON, 2014, p. 67, free translation).

Permitting the medicinal use of the plant means savings. As it acts in several areas, it reduces the number of medicines needed for different treatments; more expensive drugs could be exchanged for simple drops of cannabis oil (BEZERRA, 2019, p. 14).

In Brazil, the lack of a drug capable of reducing the occurrence of seizures led the parents of the little girl Anny, 5 years old, who suffered up to 80 attacks in a week (because of the rare genetic syndrome CDKL), to use cannabidiol without legal authorization. As the drug ministration was prohibited by the National Health Surveillance Agency, the child started to have seizures again, which had already been reduced to almost zero. On April 3, 2014 the child's parents obtained a court 
decision releasing the import of cannabis oil, making Anny the first person to use cannabidiol legally in Brazil (albeit in a precarious way, through the courts) (MOURA, 2015, p. 49).

At the end of 2014, the Federal Council of Medicine allowed the use of cannabidiol. In January 2015, the National Health Surveillance Agency removed cannabidiol from its list of banned substances due to the numerous surveys that report the benefits of the plant (ANVISA, 2015).

On May 6, 2015, the National Health Surveillance Agency published Collegiate Board Resolution No. 17, which defines the criteria and procedures for importing, on an exceptional basis, a cannabidiol-based product in association with other cannabinoids, including tetrahydrocannabinol, per individual, for own use, by prescription from a legally qualified professional for health treatment (ANVISA, 2015).

In 2016, through Collegiate Board Resolution no. 128/16, the list of cannabidiol-based drugs was updated, which has a simpler authorization process by National Health Surveillance Agency. The medications are: Cibdex Hemp CBD Complex, Hemp Blend Real Scientific Hemp Oil (RSHO) CBD, Revivid LLC Hemp Tincture, CBDRX CBD Oil, Charlotte Web Hemp Extract, Endoca Hemp Oil, Elixinol Hemp Oil CBD, EVR Hemp Oil CBD, Mary's Elite CBD Remedy Oil, Purodiol CBD. Still in 2016, the National Health Surveillance Agency announced the registration of the drug Mevatyl for the treatment of spasticity (ANVISA, 2016).

In April 2018, it was announced by the laboratory Prati Donaduzzi in partnership with the University of São Paulo, that a research into the production of cannabidiol is in the final stages of clinical trials. In addition, they announced that the medication wouldl be available by the end of 2018. According to the researchers, the production in the country will guarantee higher quality and lower cost of the medication. The Brazilian Cannabinoid Research Center is also studying the possibility of producing cannabidiol in a synthetic way, which would eliminate the need to use cannabis in plants (G1 PR E RPC CASCAVEL, 2018).

Recently, on December 3, 2019, the National Health Surveillance Agency published Collegiate Board Resolution no. 327, releasing not only the importation, 
but the manufacture, commercialization, prescription, dispensing, monitoring and inspection of "cannabis products containing as active principle exclusively vegetable derivatives or phytochemicals from cannabis", which "must predominantly contain cannabidiol and no more than $0.2 \%$ of tetrahydrocannabinol" (ANVISA, 2019).

The National Health Surveillance Agency also regulated, in article 4, sole paragraph, of the Collegiate Board Resolution no. 327/2019, that: "cannabis products may contain THC content above $0.2 \%$, provided that they are intended for palliative care exclusively for patients without other therapeutic alternatives and in situations irreversible or terminal clinics" (ANVISA, 2019).

The National Health Surveillance Agency, due to unknown reasons, determined the provisional archiving of the analysis of the authorization for importing and planting the seed. This, inevitably, will imply the cost of the product, since currently the raw material must be imported from other countries, which makes the production process more expensive.

\section{THE AXIOLOGICAL GAP IN THE PROHIBITION OF IMPORT AND PLANTING OF CANNABIS SEEDS FOR MEDICINAL PURPOSES IN BRAZIL AND ITS INTEGRATION}

Tthe analysis of the aforementioned legislation shows that there is no plausible reason to release the import and commercialization of cannabis-derived medicines and not to release the cultivation of the same plant with the same attributes in the national territory.

It is also important to note that Resolution of the Collegiate Board no. $327 / 19$ did not prohibit the import of the seed and its planting, but only did not authorize it. However, as Ordinance no. 344/1998 includes tetrahydrocannabinol as a narcotic 
substance, without clarifying the prohibited percentage, any handling of it will be applied under the terms of Law no. 11,343/06, known as "Drugs Law"1.

As soon as the National Health Surveillance Agency authorizes the import and sale of cannabis-based products, it is a logical premise that they must be removed from the list of narcotics. There is no reasonable justification for preventing the import and planting of cannabis in the national territory. It is possible to conclude that there is a gap in the aforementioned regulations.

As Karl Engisch clarifies that (2001, p. 276 e 279),

\begin{abstract}
A gap is an unsatisfactory incompleteness within the whole. Applied to law, the concept of gap means that it is an unsatisfactory incompleteness within a legal whole. (...) The gaps are deficiencies of positive law (of legislated or customary law), apprehensible as shortcomings or shortcomings in the content of legal regulations for certain factual situations in which such regulations are expected and in which such shortcomings admit their removal through a legal-integrative judicial decision. The gaps appear, therefore, when neither the law nor customary law give us an immediate answer to a legal question.
\end{abstract}

In the specific case, one is particularly interested in the species of the axiological gaps ${ }^{2}$, since regulating the use of cannabis for medicinal purposes, excluding the authorization to import and plant the seed in Brazil generates an unfair result for Brazilian society.

Once the axiological gap has been identified, it is necessary to point the way to fill this void, producing an appropriate legal application for the standard in question. This is the standard integration procedure.

At this point, it is worth emphasizing the lesson of Miguel Reale (2002, pp. 295-296) on the differentiation between the figures of interpretation, integration and

\footnotetext{
1 It should be noted that art. 31 of Law $11.343 / 06$ provides that: "prior authorization from the competent authority is essential to produce, extract, manufacture, transform, prepare, possess, keep in deposit, import, export, re-export, remit, transport, exhibit, offer, sell, buy, exchange, assign or acquire, for any purpose, drugs or raw materials for their preparation, observing the other legal requirements".

${ }^{2}$ In the classification of Maria Helena Diniz (2002, p. 95), which we have adopted, it is possible to identify three kinds of gap, namely, a) the normative, in the absence of a standard for solving the case; b) the ontological, when, if there is a rule, it does not correspond to the social facts; $c$ ) the axiological, in the absence of a fair standard, if the application of the standard results in an unsatisfactory or unfair solution.
} 
application of the norm. The application of the law is due to the competence of an authority, which imposes a legal guideline in a specific case. Before applying the law, however, the authority needs to interpret it, proceed with the choice, of axiological nature, of several possible meanings for the norm. But, if the standard has a gap, the interpretation process is not enough to fill this gap, making it necessary to use integration.

The mechanisms for integrating the gaps are provided in the Law of Introduction to the Rules of Brazilian Law, in articles 4 and 5. It is about the analogy, customs, general principles of law and equity, to be used in that order in the integration procedure.

As stated by Tércio Sampaio Ferraz Jr. (2007, p. 314),

We cannot forget that the different national legal systems face integration differently, with those that expressly determine which instruments, as in the case of Brazil, but also those that are omitted in this regard, generating a kind of second degree gap for lack of a rule on how to fill in, as in the case of German law.

Within this framework, there is no analogy or custom that can be applied to the case investigated; it is worth pointing to the hypothesis of integration by general principles of law, the appropriate route for the problem studied in this opportunity.

The general principles of law, according to Maria Helena Diniz (2002, p. 233), are normative elements applicable in specific problematic cases, regardless of whether they are positive or not, in norms; therefore, not being mere maxims or heuristic rules. They have a general character, but proceed from an objective, ethical and social estimation.

In defining the legal principles, Karl Larenz (1985, pp. 32-33) explains that these are "los pensamientos directores de una regulación jurídica existente o posible. En sí mismos no son todavía reglas susceptibles de aplicación, pero pueden transformarse en reglas"3.

${ }^{3}$ The guiding thoughts of an existing or possible legal regulation. In themselves they are not yet applicable rules, but they can be transformed into rules (free translation). 
In the present case, the integration of Collegiate Board Resolution no. 327/19 to authorize the import and planting of cannabis seeds for medicinal purposes runs through the application of general principles of law, such as human dignity, equality and social solidarity, as well as the principles of economic activity.

According to the Constitution of 1988 , in its article 1, III, the Federative Republic of Brazil has as one of its foundations the dignity of the human person (BRASIL, 1988). The use of cannabis for medicinal purposes ensures that the basic needs of certain patients are met, which has not been achieved in these cases by conventional medicine.

Kant understands that human dignity is a congenital and inalienable quality of all human beings, which prevents their objectification and materializes through the capacity for self-determination that individuals possess through reason. Its existence does not depend on legal recognition, as it is an innate and ethical asset, placing itself above cultural specificities. It persists even in societies that do not respect it. Its legal nature can be divided into two maxims: "not treating the human person as a simple means and ensuring the vital needs of the human person" (RECKZIEGEL, 2016, p. 234-235. KANT, 1974).

Sarlet and Fensterseifer (2007, p. 69-94), when dealing with human dignity, explain that this concept is projected both in a range of rights of a defensive nature (negative), as well as a service one (positive), also implying fundamental duties. It relates to a range of subjective and objective legal positions, with the function of protecting the human existential condition against any violations of its scope of protection, ensuring the free and full development of the personality of each human being. The authors also address the social dimension of human dignity, since this concept is not related only to an individual, but to his relationship with the other.

In the same line, the Constitution provides in caput of article 5 the guarantee to Brazilians and foreigners residing in the country of the inviolability of the right to life, freedom, equality, security and property (BRASIL, 1988).

The context reveals that, in view of the Constitution, in its article 196, health is a right for all and a duty of the State. The search for positive health provision has 
taken Brazilians to the courts of justice, whether they are users of the public or private health system, in order to obtain judicial authorization for the importation of cannabidiol, for medicinal purposes (MELO; SANTOS, 2016, p. 45).

The right to health is paramount and links the legislative, executive and judicial powers in guaranteeing its execution. The patients that need medication derived from marijuana are supported by the Constitution on the right to health (RECKZIEGEL, 2019, p. 58).

In order to guarantee the right to health, it is necessary to have a financial condition compatible with the price of the imported medicine, it has as a consequence that the cheapening of the product produced from cannabis planted in Brazil is still a matter of impact on equality.

Specifically on the principle of equality, it is necessary not to confuse its formal aspect with its material aspect. The characteristic idea of equality that everyone is equal before the law represents the formal aspect of the principle, whereby the law must be applied objectively, without discrimination.

In the words of Konrad Hesse (1998. p. 330):

Cada um é, em forma igual, obrigado e autorizado pelas normalizações do direito, e, ao contrário, é proibido a todas as autoridades estatais, não aplicar direito existente a favor ou à custa de algumas pessoas ${ }^{4}$.

One cannot forget the relevance of recognizing the material aspect of equality, so that different people are entitled to unequal treatment. According to Konrad Hesse (1988, p. 330), the principle of equality "prohibits unequal regulation of equal facts; equal cases must find equal rule. The question is, which facts are the same and, therefore, should not be regulated unevenly".

When the National Health Surveillance Agency ceases to authorize the import and planting of cannabis, but authorizes the import and commercialization of the same product, it treats the same as unequal, being against the constitutional

\footnotetext{
${ }^{4}$ Each is equally equal, obliged and authorized by the normalization of the law, and, on the contrary, it is prohibited for all state authorities not to apply existing law for or against some people (free translation).
} 
principle of equality. The import of phytotherapic to the detriment of national production will restrict access of the product to those people who lack the means to acquire them.

The present issue also implies an understanding of the universe of private law and the latent dialectic between its general principles, applicable to all segments of business activity, such as free enterprise, free competition and the social and solidarity function of the company.

Among the principles of economic activity that deserved mention in the constitutional text (article 170), it is highlighted free initiative, free competition, the social function of property, the protection of consumers and the environment.

Jaime Santos Briz (1966, p. 26) clarifies the freedom that characterizes the business activity:

[...] la libertad de industria en sentido amplio (como libertad de creación de empresas y libertad de economía) encierra la libertad de competencia, la libertad de contratación, la de producción y la de consumo ${ }^{5}$.

The exploitation of the market, as stated by Rizzatto Nunes (2013, p. $102-$ 103), is obviously based on free initiative, guaranteed constitutionally. However, the joint interpretation of the principles of economic activity allows to conclude that: a) the consumer market open to exploitation does not belong to the explorer, but to society, and exists due to it; b) the explorer has responsibilities to settle in the exploratory act; c) profit is a logical result of exploitation, but it cannot be unlimited to the point of characterizing damage to the market and to society; d) monopoly, oligopoly and any other practices aimed at market domination are prohibited to individuals; and e) since the profit is legitimate, the risk is exclusively of the entrepreneur, due to one's free choice to undertake the activity aimed at the consumer and cannot pass this burden ahead.

\footnotetext{
${ }^{5}[\ldots]$ Freedom of industry in a broad sense (such as freedom of business creation and freedom of economy) contains freedom of competition, freedom of contract, production and consumption (free translation).
} 
According to the author, the market, even as an economic fiction, produces concrete effects on society. It is not the ownership, possession or use of anyone in particular or a specific group, but belong to society. This concrete effectiveness is confirmed by its daytime and historical exploration, which cannot harm the market itself or society. It is composed not only of entrepreneurs, but also of consumers who are the agents that make the market exists (NUNES, 2013, p. 103).

The spirit of the functionalization of legal institutes acts as a counterbalance and is also present in the Constitution - the social value of free enterprise - (articles 1, IV, and 170, caput); in the social function of contracts, provided for in the Civil Code (article 421); and in the express mention of "company social function" materialized in the Corporations Law (Law no. 6,404/76, article 154, caput).

In summary, the social function of the company is derived from the systematic interpretation of the aforementioned legal provisions. It limits the will and the interest of the capital holders, replacing the arbitrary power of the owner of the company with the balance that must come to exist between the forces that cooperate for the development of business purposes and social interest.

In addition, solidarity as a function of the company, in connection with fundamental rights of the third dimension, stems from the principle of solidarity, provided for in Article 3, item I, of the Constitution. It is based on the construction of a free, just and egalitarian society, solidifying the idea of community based on the common good.

Habermas analyzes solidarity (2002, p. 75):

Deontological justice demands solidarity on its other side. In this case, these are not two moments that complement each other, but aspects of the same thing. All autonomous morals have to solve, at the same time, two tasks: by claiming equal treatment, and with it an equivalent respect for the dignity of each one, it asserts the inviolability of individuals in society; and at the same time that it requires solidarity on the part of individuals, as members of a community in which they are socialized, it protects inter-subjective relationships of mutual recognition (our translation). ${ }^{6}$

6 Text in Portuguese: "A justiça concebida deontologicamente exige, como sua outra face, a solidariedade. Não se trata, neste caso, de dois momentos que se complementam, mas de aspectos da mesma coisa. Toda moral autônoma tem que resolver, ao mesmo tempo, duas tarefas: ao 
By allowing the use of cannabis for commercial purposes in Brazil and omitting to import and plant its seeds, the National Health Surveillance Agency prevents the implementation of the principles of economic activity, because it limits the freedom of national companies in an unjustified way, interfering in their competitiveness in relation to foreign companies that will profit in the Brazilian market.

On the other hand, by stopping generating jobs, collecting taxes and attending to a market in dire need of medicinal products originating from cannabis, Brazilian companies interested in importing and planting these seeds were curtailed in relation to social function and social solidarity. Such a situation has implications for the economic scenario, unacceptably harming national development and the economy.

\section{FINAL CONSIDERATIONS}

The Brazilian State has authorized the manufacture, import, commercialization and prescription of cannabis for medicinal purposes through monitoring and inspection. But, at the same time, it stopped regulating the import and planting of seeds in Brazil, which implies submitting this practice to Law no. 11,343 / 06 . This generated a legal technical issue characterized as an axiological gap.

Such a situation that generates injustice refers to the fact that, without the liberation of importing and planting seeds in Brazil, cannabis-based medicines will cost more to Brazilian consumers. In addition, from another perspective, Brazilian companies interested in operating in this sector are at a competitive disadvantage compared to foreign ones, preventing the emergence of a new economic market,

reivindicar trato igual, e com ele um respeito equivalente pela dignidade de cada um, faz valer a inviolabilidade dos indivíduos na sociedade; e ao mesmo tempo em que exige a solidariedade por parte dos indivíduos, como membros de uma comunidade na qual são socializados, protege as relações intersubjetivas de reconhecimento recíproco". 
generating jobs and taxes. All of this, consequently, has an impact on the national development.

The situation is aggravated when considering that medical studies recognized by the National Health Surveillance Agency vehemently conclude by the benefits of using cannabis in the treatment of certain diseases. The proven efficiency of such remedies, that is superior to that observed in conventional medicine for certain diseases, does not, in itself, guarantee the right to health, if there is no cheaper access to medicines and the cost rises in the process of importing them.

If the medicinal properties are proven and there is already a rule on the legality of the use of cannabis for medicinal purposes, there is no need to talk about the risk of planting for the population due to the potential increase in recreational use of marijuana. There is no specific study of this connection, but merely conjectures. It is important to note that the National Health Surveillance Agency regulates the monitoring and inspection of cannabis for medical purposes.

Brazil has the capacity to produce the components of cannabis perfectly when it comes to green medicine, and the legislation can be faster, more objective and fair. The axiological gap now reported integrates, without great difficulty, with respect to the general principles of law, such as human dignity, equality and social solidarity, as well as the principles of economic activity.

The battle over the legalization of the medical use of cannabis will not be completely successful, contributing to a better quality of life for the Brazilian population, until the authorities define the issue of importing and planting the seeds in question, which deserves, in addition to the effort academic, the strength of social mobilization.

\section{REFERENCES}

ANVISA - Agência Nacional de Vigilância Sanitária. Canabidiol é reclassificado como substância controlada. 21 jan. 2015. Available at: $<$ http://portal.anvisa.gov.br/noticias/-/asset_publisher/ 
FXrpx9qY7FbU/content/canabidiol-e-reclassificado-como-substanciacontrolada/219201>/>. Access on: 14 Oct. 2019.

Atualizada lista de produtos com canabidiol importados. 05 dez. 2016. Availabe at: <http://portal.anvisa.gov.br/noticias/-/asset_publisher/ FXrpx9qY7FbU /content/atualizada-lista-de-produtos-com-

canabidiolimportados/219201/pop_up?_101_INSTANCE_FXrpx9qY7FbU_viewMode $=$ print\&_101_INSTANCE_FXrpx9qY7FbU_languageld=pt_BR $>$. Access on: 15 Oct. 2019.

. Resolução de Diretoria Colegiada - RDC n. 17, de 6 de maio de 2015. Define os critérios e os procedimentos para a importação, em caráter de excepcionalidade, de produto à base de Canabidiol em associação com outros canabinóides, por pessoa física, para uso próprio, mediante prescrição de profissional legalmente habilitado, para tratamento de saúde. $11 \mathrm{p}$. Available at: <http://portal.anvisa.gov. br/documents/10181/2867344/\%283\%29RDC_17_20 15_COMP.pdf/ d0b13b61-7b6d-476c-8177-6b866c7a9b10>. Access on: 15 Oct. 2019.

. Resolução de Diretoria Colegiada - RDC n. 327, de 9 de dezembro de 2019. Dispõe sobre os procedimentos para a concessão da Autorização Sanitária para a fabricação e a importação, bem como estabelece requisitos para a comercialização, prescrição, a dispensação, o monitoramento e a fiscalização de produtos de Cannabis para fins medicinais, e dá outras providências. 16 p. Available at: $\quad<$ http://www.in.gov.br/en/web/dou/-/resolucao-da-diretoria-colegiada-rdc-n-327de-9-de-dezembro-de-2019-232669072>. Access on: 6 Jan. 2020.

. Sobe para 297 o número de pedidos de importação de Canabidiol recebidos. Brasília, 2014. Disponível em: http://s.anvisa.gov.br/wps/s/r/cWX3. Acesso em 17 out. 2019.

BEZERRA, Gabriela A. V. A legalização da cannabis para fins medicinais. 2019. Disponível em: http://repositorio.ufersa.edu.br/handle/prefix/1828. Acesso em 12 out. 2019.

BRIZ, Jaime Santos. La contratación privada: sus problemas en el tráfico moderno. Madri: Montecorvo, 1966.

BURGIERMAN, Denis Russo. O fim da guerra: a maconha e a criação de um novo sistema para lidar com as drogas. São Paulo: Leya, 2011.

BRASIL. Constituição da República Federativa do Brasil. Brasília, DF: Senado, $1988 . \quad$ Available at: <http://www.planalto.gov.br/ccivil_03/constituicao/constituicao.htm>. Acesso em: 06 jan. 2020. 
Lei 11.343/2006 - Lei das Drogas. Brasília, 2006. Disponível em: http://www.planalto.gov.br/ccivil_03/_ato2004-2006/2006/lei/111343.htm. Access on: 18 Oct. 2019.

. Ministério da Saúde. Portaria no 344 de 12 de maio de 1998. Aprova o Regulamento Técnico sobre substâncias e medicamentos sujeitos a controle especial. Diário Oficial da União. Brasília, 15 mai 1998. Available at: <http://bvsms.saude.gov.br/bvs/saudelegis/svs/1998/prt03

44_12_05_1998_rep.htm >. Access on: 17 Oct. 2019.

DINIZ, Maria Helena. As lacunas do direito. 7 ed. atual. São Paulo: Saraiva, 2002.

ENGISCH, Karl. Introdução ao pensamento jurídico. Tradução J. Baptista Machado. 8 ed. Lisboa: Fundação Calouste Gulbenkian, 2001.

FERRAZ JR., Tércio Sampaio. Introdução ao estudo do direito: técnica, decisão, dominação. 5 ed., 2. reimpr. São Paulo: Atlas, 2007.

FRANÇA, J.M.C. História da Maconha no Brasil. São Paulo: Três Estrelas, 2015.

G1 PR E RPC CASCAVEL. Laboratório de Toledo deve ser o primeiro a produzir e vender extrato de canabidiol no país. Toledo/ PR, $04 \mathrm{abr}, 2018$. Available at: $<$ https://g1.globo.com/pr/oeste-sudoeste/noticia/laboratorio-de-toledo-deve-ser-oprimeiro-a-produzir-e-vender-extrato-de-canabidiol-no-pais.ghtml>. Access on: 15 Oct. 2019.

G1 RIBEIRÃO E FRANCA. USP em Ribeirão Preto terá 1 centro de pesquisas de canabidiol do Brasil. Ribeirão Preto/SP, 31 Jan. 2017. Available at: <http://g1.globo.com/sp/ribeirao-preto-franca/noticia/2017/01/usp-em-ribeirao-pretotera-1-centro-de-estudos-de-canabidiol-do-brasil.html>. Access on: 15 Oct. 2019.

HABERMAS, Jürgen. Aclaraciones a la ética del discurso. Madrid: Trotta, 2002.

HESSE, Konrad. Elementos de Direito Constitucional da República Federal da Alemanha. Tradução de Luís Afonso Heck. Porto Alegre: Sergio Antonio Fabris, 1998.

KANT, Immanuel. Crítica da razão pura e outros textos filosóficos. Tradução de Paulo Quintela. São Paulo: Abril Cultural, 1974.

LARENZ, Karl Larenz. Derecho justo. Tradução Luis Díez-Picazo, Madri: Civitas, 1985.

MASSON, C. Direito penal esquematizado. São Paulo: Método, 2014. 
MELO, Leandro A; SANTOS, Alethele O. O uso do Canabidiol no Brasil e o posicionamento do Órgão Regulador. Cad. Ibero-Amer. Dir. Sanit., Brasília, 5(2):43-55, abr.jun, 2016.

MOREAU, R.L.M. Cannabis. São Paulo: Atheneu, 2008.

MOURA, M. Drogas: Reprimir não funciona. Época. Rio de Janeiro, 2015.

NUNES, Rizzatto. Curso de direito do consumidor. 8 ed. rev. e atual. São Paulo: Saraiva, 2013.

PEDRINHA, Roberta Duboc. Notas sobre a política criminal de drogas no Brasil: elementos para uma reflexão crítica. XVII Encontro Preparatório para o Congresso Nacional do CONPEDI. Manaus: CONPEDI, 2008, p. 5.486-5.503.

REALE, Miguel. Lições preliminares de direito. 27 ed. atual. 7 tir. São Paulo: Saraiva, 2002.

RECKZIEGEL, J. O uso da Maconha Medicinal no tratamento de doenças em face da Dignidade Humana. Santa Catarina, 2019. Available at: DOI: http://dx.doi.org/10.20912/rdc.v14i32.2675. Access on: 18 Oct. 2019.

Dignidade humana em risco: existem limites para experiências científicas? Curitiba: Prismas, 2016.

ROBINSON R. O Grande Livro da Cannabis: Guia completo de seu uso industrial, medicinal e ambiental. Rio de Janeiro: Jorge Zahar, 1999.

SARLET, I. W.; FENSTERSEIFER, T. Algumas notas sobre a dimensão ecológica da dignidade da pessoa humana e sobre a dignidade da vida em geral. Revista Brasileira de Direito Animal, n. 3, p. 69- 94, 2007.

SOUBHIA, Paula Christiane. Período de detecção de canabinóides urinários por imunofluorescência polarizada em população usuária de cannabis. Dissertação de Mestrado (Ciências Farmacêuticas, Área de Toxicologia e Análises Toxicológicas). Universidade de São Paulo, São Paulo, 1999.

VIDAL, Sergio. A regulamentação do cultivo de maconha para consumo próprio: uma proposta de Redução de Danos. In: NERY FILHO, A., et al. orgs. Toxicomanias: incidências clínicas e socioantropológicas. Salvador: EDUFBA; Salvador: CETAD, 2009, pp. 61-96. Available at: <http://books.scielo.org/id/qk/pdf/nery-978852320882005.pdf>. Access on: 17 Oct. 2019. 